\title{
CORRESPONDENCE
}

\section{Soft-centred Earth}

SIR,-In the article "A Soft-centred Earth" (Nature, 235, 304; 1972), your correspondent appears to be implying that the detection of seismic pulses reflected from the inner core boundary announced by Engdahl et al, at the 1970 meeting of the Seismological Society of America was a novelty. In the interest of accuracy, and without diminishing in any way the accomplishment of Engdahl et al., let me point out that more than 10 years ago Caloi (Geophys. J. Roy. Astron. Soc., 4, 139 ; 1961) reported the detection of a PKiKP phase in records of Aegean earthquakes $\left(\Delta<20^{\circ}\right)$ obtained at Tolmezzo (Northern Italy). The conclusion he offered was that "The existence of a reflecting surface, as a boundary of the inner core, is a proof of the solid state of the inner core itself". His results were cited by Bullen (An Introduction to the Theory of Seismology, 3rd ed., 221 ; 1965), and therefore cannot be said not to have been presented to a wide audience of seismologists.

$$
\begin{aligned}
& \text { Yours faithfully, } \\
& \text { G. RANALLI }
\end{aligned}
$$

Department of Geology,

Carleton University,

Ottawa

\section{Concorde}

SIR,-I write to comment on the passage in your issue of Nature (234, 372; 1971): "In other words, the Concorde has helped to demonstrate that it can only be a matter of time before supersonic aircraft are in regular airline service, providing passengers with the immense convenience of faster longdistance journeys and providing airlines with profits commensurate with the service they will be able to provide." Surely Concorde has demonstrated no such thing. What has been shown so far is that a supersonic airliner is probably feasible from the limited viewpoint of aeronautical engineering and that sonic bangs from such large aircraft are not tolerable as a daily event for humans. It does not follow that restricting bangs to oceans is free from objection, or that there can ever be profits from flying such expensive aircraft without boom corridors overland. It is impossible to fly from London to Sydney or Tokyo without flying long distances over inhabited countries, and a bang is just as disturbing to an individual irrespective of whether he lives in a sparsely or densely populated place.

A number of other issues each of which on its own could put an end to commercial supersonic flying are still to be resolved. Who, for example, has refuted Professor Harold Johnston's hypothesis of the effects on ozone by supersonic transport exhaust? The ad hoc review panel formed by the National Academy of Sciences to consider this matter released a report in December which states "... there appears to be general agreement that Harold Johnston's conclusions as reported in his paper, 'Reduction of Stratospheric Ozone by Nitrogen Oxide Catalysts from SST Exhaust', are credible .... and that the possibility of serious effects on the normal ozone content cannot be dismissed . . .". This, sir, contradicts your own view that "nobody is seriously worried about the effects of exhaust gases on the stratosphere ...."

One must expect optimism for supersonic airliners from the manufacturers of Concorde, but caution seems more appropriate from a scientific journal.

$$
\begin{aligned}
& \text { Your faithfully, } \\
& \text { NeviLl MotT }
\end{aligned}
$$

Cavendish Laboratory,

Free School Lane, Cambridge

\section{Atmospheric Mystery}

SIR,-I would greatly appreciate comment on my observation of the following event.

I was standing on top of the Puy Mary, 1,787 metres high, the highest of the volcanic cones in the range of the Cantal mountains. To the north, about 1-2 miles away, I saw lightning coming out from a black bank of clouds and heard the thunder about 5-6 s later. However, I felt a strong blast of hot air reaching me before $I$ could hear the thunderclap. This happened several times in quick succession, though I did not time the length of the intervals between each lightning.

I think I am right in saying the blast, which was fairly strong, was the aftermath of the last lightning but one. It was almost silent and no doubt travelled at less than the speed of sound.

I have been near thunderstorms often enough in my life, in the Alps and on the plains, but this blast of hot air was something new to me, and I have not met anybody who had made a similar observation; hence my request for comment.

Yours faithfully,

\section{H. WORTH}

14 Clare Lawn Avenue,

East Sheen,

London SW14

\section{Avery et al.}

SIR,-I have before me Peyton Rous's copy of the reprint of the article by Avery, MacLeod and McCarty recently discussed by H. V. Wyatt (Nature, 235, $86 ;$ 1972). There can be little doubt that Avery gave this reprint to Rous at the time of its original appearance. On it Rous wrote, as an instruction to his secretary, "Please file under genetics". She did.

Your faithfully, Paul F. Cranefield

The Rockefeller University,

New York,

New York 10021

\section{Bertrand Russell}

SIR,-I am writing, with the cooperation of the Bertrand Russell estate, a major life of the late Bertrand Russell, and would be grateful to hear from any of your readers who have correspondence, photographs or information likely to be of use to a biographer.

Any material sent to me at the address given below will be returned without delay.

Yours faithfully,

$$
\text { Ronald W. Clark }
$$

10 Campden Street,

Kensington,

London $W 8$ 